Dicle Üniversitesi Veteriner Fakültesi Dergisi
https://dergipark.org.tr/tr/pub/duvetfd
Vaka/Case Report
Dicle Üniv Vet Fak Derg 2021;14(2):145-147
DOI: 10.47027/duvetfd.929406

\title{
Congenital Unilateral Lateral Patellar Luxation in a Simmental Calf
}

\author{
Sıtkıcan OKUR ${ }^{1, a, 凶}$, Ömer Tarık ORHUN ${ }^{1, b}$, Ayşe GÖLGELi ${ }^{1, c}$, Uğur ERSÖZ $^{1, d}$, Latif Emrah YANMAZ ${ }^{1, e}$ \\ ${ }^{1}$ Department of Surgery, Faculty of Veterinary Medicine, Atatürk University, Erzurum, TÜRKIYE \\ aORCID: 0000-0003-2620-897X; b ORCID: 0000-0003-4184-8879; ' ORCID: 0000-0002-9798-8638 \\ dORCID: 0000-0002-1687-2327; eORCID: 0000-0001-5890-8271
}

\begin{tabular}{ccc}
\hline Geliş Tarihi/Received & Kabul Tarihi/Accepted & Yayın Tarihi/Published \\
28.04 .2021 & 27.05 .2021 & 31.12 .2021 \\
\hline
\end{tabular}

\begin{abstract}
In this case report, the surgical treatment of a calf with congenital, unilateral lateral patellar luxation with clinical, radiography, and computed tomography findings is presented. A 5-day-old calf was referred due to an extremely flexed knee joint with extremity weakness. Orthopaedic, radiographic, and computed tomographic examination demonstrated a grade 3 unilateral lateral patellar luxation with normal stifle bone anatomy. Surgery includes lateral release with medial imbrication of the medial retinaculum and resulted in the repositioning of the patella. After the surgery, the limb was immobilized for ten days with splint bandage. The calf became a normal stance and gait following six weeks after the surgery. In this case, it was concluded that the imaging methods of the patellar luxations that can be observed naturally in calves facilitate the diagnosis and can be successfully treated with lateral release and medial imbrication compared to many methods mentioned in the literature.
\end{abstract}

Key Words: Calf, congenital, lateral, luxation, patella

Bir Buzağıda Kongenital Unilateral Lateral Patella Luksasyonu

Öz

Bu olguda, konjenital ve unilateral patella luksasyonu bulunan bir buzağının, cerrahi sağaltımı ile birlikte klinik, radyografik ve bilgisayarlı tomografi bulguları sunulmaktadır. Beş günlük bir buzağı, arka eksremitesin de güçsüzlük ile diz ekleminde aşırı fleksiyon şikayetiyle getirildi. Ortopedik, radyografik ve bilgisayarlı tomografi sonucunda diz eklemi kemiklerinin anatomik olarak normal olmasıyla beraber, unilateral 3. derece bir patella luksasyonu olduğu belirlendi. Cerrahi olarak, medial retinakulumun ile birlikte medial imbrikasyonu ve lateral serbestleştirme işlemleri uygulanarak patellanın yeniden konumlandırılması sağlandı. Operasyon sonrası buzağının eklemi 10 gün süreyle destekli bandaj uygulandı. Operasyondan altı hafta sonra hayvan buzağının normal olarak ayağını ilgili ekstremitesini normal şekilde kullanabildiği gözlemlendi. Bu olguda buzağılarda doğmasal olarak gözlemlenebilen patella luksasyonlarının görüntüleme yöntemlerinin tanıyı kolaylaştırdığı, litaratürde belirtilen pek çok yönteme nazaran lateral serbestleştirme ile medial imbrikasyon uygulamasıyla birlikte başarılı bir şekilde tedavi edilebildiği sonucuna varılmıştır.

Anahtar Kelimeler: Buzağı, kongenital, lateral, luksasyon, patella

\section{INTRODUCTION}

Lateral patellar luxation (LPL) in calves is a rare disorder in which unilateral or bilateral involvement has been observed (1). Its origin can be congenital or secondary $(1,2)$. Causes of congenital patellar luxation involve weakness of the medial patellofemoral ligament, hypoplasia of the trochlear groove, medial rotation of the tibia, and the posture position in the uterus (3). LPL may also be affected by hypoplastic vastus medialis. If this muscle does not act properly, it does not balance the force of the vastus lateralis, which resulting in displacing the patella outside (4). Direct or indirect trauma to the stifle can also cause acquired patella luxation due to patellofemoral ligament deformation or a distal femoral fracture (5). Calves can be affected following the birth or within weeks (2). Calves with a displacement of the patella are suffering from pain, cartilage damage, and arthritis (4). The LPL in calves is diagnosed with physical and radiological examination (1). The treatment methods of patella luxation include, lateral or medial desmotomy, medial (lateral) imbrication of the joint capsule and fascia, lateral (medial) tibial tuberosity transposition, osteotomies of femur or tibia, and trochleoplasty (2).

The present study describes the clinical and radiographic findings and the surgical treatment of LPL in a Simmental calf with unilateral involvement.

\section{CASE REPORT}

A 5-day-old male pure-bred Simmental calf weighing $19.5 \mathrm{~kg}$ was presented to Atatürk University, Faculty of Veterinary Medicine Animal Hospital, with severe unilateral left hind limb lameness and an inability to completely extend the stifle. The owner reported the calf has been reluctant and difficult to stand up following birth. 
During the clinical evaluation, no abnormality was observed in the calf except for mild swelling over the left stifle, irregular posture, and gait. The patella was dislocated immediately to the lateral side of the bone after manual repositioning in the trochlear groove of the femur. A grade III unilateral congenital LPL was diagnosed. The quadriceps femoris muscle was also laterally deviated and poorly developed. The patellar reflex and withdrawal reflex were neurologically determined to be normal.

The radiographic examination was performed under the xylazine $(0.1 \mathrm{mg} / \mathrm{kg} \mathrm{IM}$, Xylazinbio $2 \%$, Bioveta PLC, Komenskeho, Czech Republic) and propofol (4 mg/kg IV, Propofol \% 1, Fresenius, Istanbul, Turkey) administration. The stifle radiographs obtained craniocaudal and mediolateral directions was confirmed lateral displacement of the left patella (Figure 1a). Computed tomography (CT) was also obtained for the detailed examination of the stifle joint (Figure 2a).

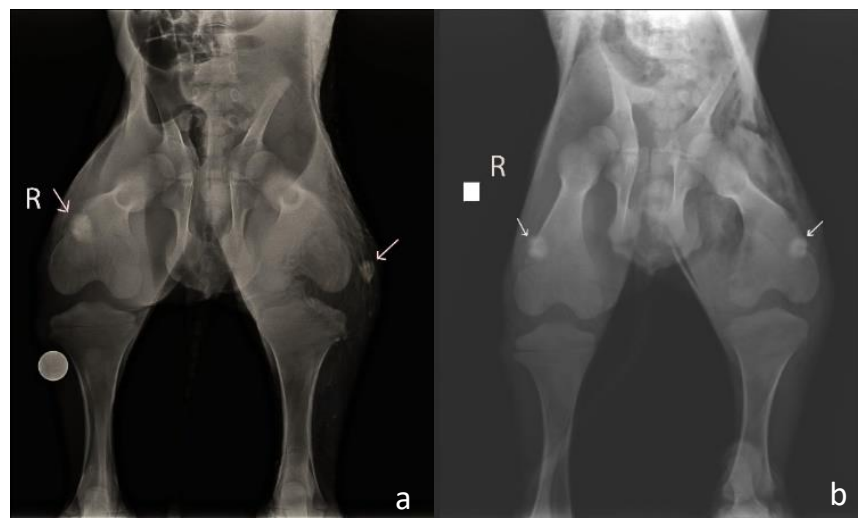

Figure 1. (a) Determination of the laterally luxated patella by craniocaudal radiography (b) Postoperative radiographic image of the patella

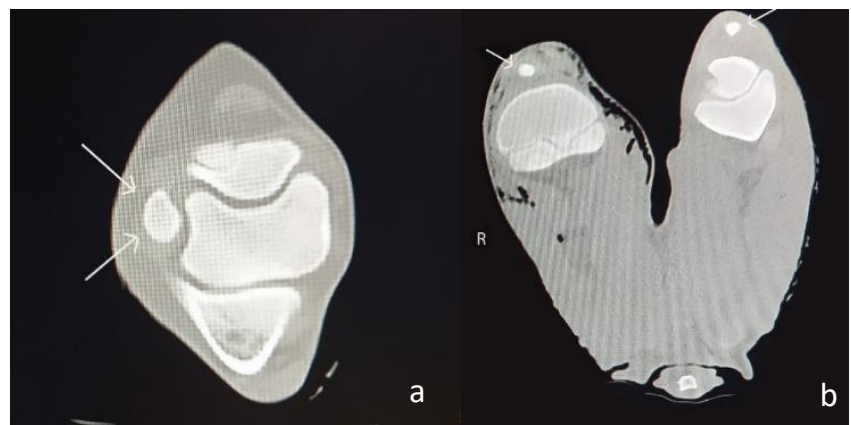

Figure 2. (a) Determination of the laterally luxated patella by computed tomographic image. (b) Postoperative computed tomographic image of the patella

The calf was operated on after 8-hour fasting. Before the surgery, flunixin meglumine $(2.2 \mathrm{mg} / \mathrm{kg} \mathrm{IM}$, Flumeglin, Teknovet, Istanbul, Turkey) and cefazoline ( $22 \mathrm{mg} / \mathrm{kg} \mathrm{IV}, \mathrm{Ce}-$ famezin ${ }^{\circledR}$, Eczacibasi, Istanbul, Turkey) were administered. Premedication was performed with detomidine $(0.04 \mathrm{mg} / \mathrm{kg}$ IV, Domosedan, Zoetis, NJ, USA) and induced with ketamine ( $3 \mathrm{mg} / \mathrm{kg} \mathrm{IV}$, Ketasol, Richter Phama, Wels, Austria). An isotonic crystalloid fluid ( $\mathrm{NaCl} 0.9 \%$ ) was administered at a 10 $\mathrm{ml} / \mathrm{kg} / \mathrm{h}$ constant rate during the surgery.
The calf was positioned in dorsal recumbency and aseptic preparation of the skin was achieved by using a hanging limb technique. A $8 \mathrm{~cm}$ medial and lateral parapatellar incision was performed on the skin, then subcutaneous fascia, fascia genus, and joint capsule. The lateral femoropatellar ligament and gluteobiceps muscle were transected without invading the joint. The patella was replaced into the trochlear groove, then the medial joint capsule and the entire length of the patella were imbricated with simple interrupted sutures with USP 2 polydioxanone (PDS II, Ethicon, USA) without invading the femoropatellar joint. (Figure 3 ). The position of the patella was confirmed with flexion, extension, and rotation movements. The subcutaneous fascia, the subcutis layer, and the skin were closed in a simple interrupted suture with 2-0 polyglactin 910 (Vicryl, Ethicon, USA), 2-0 poliglecaprone 25, respectively (Monocryl, Ethicon, USA).

Figure 3. Intraoperative view of the lateral release of the patella (left arrow) and imbrication sutures of the medial retinaculum (right arrow)

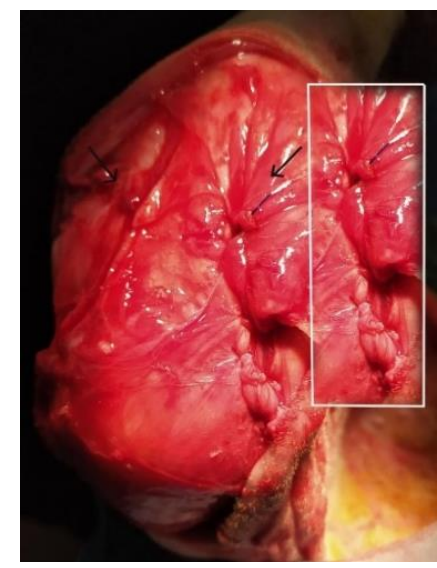

The position of the patella was confirmed by radiography (Figure $1 \mathrm{~b}$ ) and $\mathrm{CT}$ (Figure $2 \mathrm{~b}$ ) of the stifle. Postoperative treatment involved intramuscular administration of 1 $\mathrm{mg} / \mathrm{kg}$ ceftiofur (Seftivet, Vetas, Istanbul, Turkey) and 2.2 $\mathrm{mg} / \mathrm{kg}$ flunixine meglumine (Flumeglin, Teknovet, Istanbul, Turkey) for 5 days. The left limb was immobilized for 10 days following the surgery. The skin stitches were removed on the 13 days after surgery and a radiographic examination was performed to verify the condition of the patella. The calf was fully recovered in six weeks following the surgery (Figure 4).

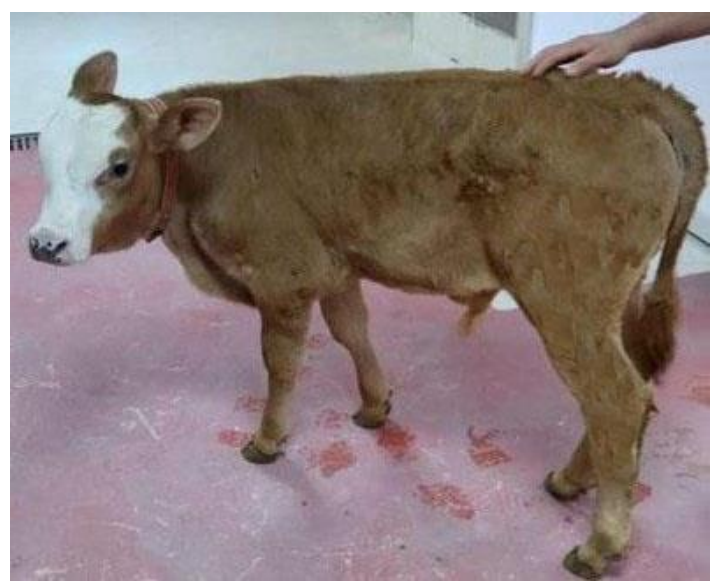

Figure 4. The calf six weeks after postoperative 


\section{DISCUSSION AND CONCLUSION}

This case report documents successful surgical treatment of unilateral, congenital lateral patellar luxation, evaluated by $\mathrm{CT}$ and radiographic in a 5-days-old Simmental calf. Congenital lateral patellar luxation is uncommonly observed in calves (5-7).

Patellar luxations have been reported in various species including dog (8), llamas (9), rabbit (10), cat (11), foal (12), and horse (13). The etiological reasons of patella dislocations are classified as congenital, traumatic, and developmental (1). Traumatic patella luxation is generally observed in large animals and mostly they are congenital (14). It has been stated that bilateral luxation is commonly congenital, while unilateral luxations are secondary (7). However, congenital patellar luxation was defined unilaterally in our case.

It has been reported that recurrence (\%35) is the most common complication of LPL in dogs (15). However, in calf the main complications are wound infection and grade 2 dislocation (1). In our case, we did not encounter any complication following the postoperative six weeks. In agreement with the literature $(4,7,16)$, the onset of clinical signs in the calf was observed to have an extremely flexed knee joint with instability and an abducted hindlimb.

Surgical treatment of patellar luxation aims to neutralize the extensor mechanism and stabilize the patella in the femoral trochlea (17). Surgical treatment of LPL includes the lateral release of the patella followed by imbrication of the medial aspect of the joint capsule (2), trochleoplasty (4), prosthetic trochlear ridge (18), or tuberosity medial transplantation (19). In additional Belge et al. reported that lateral patellar luxation in calves can be sufficiently treated with patellar anti-rotational suture technique in combination with capsuloplasty along with medial retinacular reinforcement of the joint capsule without sulcoplasty (16). In this case, the calf with LPL was treated successfully with a lateral parapatellar release incision in combination with imbrication of the medial joint capsule. This combination has also been successfully applied in goats and 1-3 month-old calves (20).

In conclusion, the aim of this study is to determine properly the surgery method in addition to the radiographic and computed tomographic image evaluation of lateral patella luxation that can be observed congenitally in calves. This study showed that congenital, lateral patellar luxation in the calf can be satisfactorily treated with lateral parapatellar release incision in combination with the imbrication of the medial joint capsule without the need for any other surgical method.

\section{REFERENCES}

1. Strous E, Willems N, Restrepo MT, Vos P, Meij B. (2019). Bilateral Lateral Patellar Luxation in a Calf. Vet Rec Case Rep. 7 (4).

2. Kalayci G, Binici C, Tünsmeyer J, et al. (2017). Diagnosis and Surgical Correction of congenital bilateral patellar luxation in two dwarf zebu calves. Tierarztl Prax Ausg G Grosstiere Nutztiere. 45(02): 112-120.
3. Brinker WO, Piermattei DL, Flo GL, DeCamp CE. (2006). Brinker, Piermattei, and Flo's Handbook of Small Animal Orthopedics and Fracture Repair. 5. Edition, Elsevier, Michigan.

4. Kim N-S, Alam Mr, Lee J-I, Park Y-J, Choi I-H. (2005). Trochleoplasty in Lateral Patellar Luxation in two Calves. J Vet Med Sci. 67(7): 723-725.

5. St-Jean G, Anderson D. (2017). External Fixation. Farm Animal Surgery. 2. Edition, Saunders, St. Louis.

6. Meagher D. (1974). Bilateral Patellar Luxation in Calves. Can Vet J. 15(7): 201.

7. Kiliç E, Özaydin I, Aksoy Ö, Öztürk S. (2008). Buzağılarda Karşılaşılan Doğmasal Bilateral Lateral Patellar Luksasyonun Parsiyel Patellar Tendon ve M. Vastus Lateralis Transpozisyonu ile Sağaltımı. Kafkas Univ Vet Fak Derg. 14(2): 185-90.

8. Kaiser S, Cornely D, Golder W, Garner M, Waibl H, Brunnberg L. (2001). Magnetic Resonance Measurements of the Deviation of the Angle of Force Generated By Contraction of the Quadriceps Muscle in Dogs with Congenital Patellar Luxation. Vet Surg. 30(6): 552-8.

9. Kaneps A, Riebold T, Schmotzer W, Watrous B, Huber M. (1989). Surgical Correction of Congenital Medial Patellar Luxation in a Llama. J Am Vet Med Assoc. 194(4): 547-8.

10. Guillier D, Decambron A, Desprez I, Pignon C, Donnelly TM. (2020). Patellar Luxation in rabbits (Oryctolagus cuniculus): 6 cases (2017-2020). J Exot Pet Med. 36: 62-7.

11. Alves E, Faria R, Varon J, Rosado I, Rezende CdF. (2017). Grade IV Medial Patellar Luxation in Cat: Case Report. Nucleus Animalium. 9(1): 119-28.

12. Gustafsson K, Hontoir F, Sutton G, Kelmer G, Tatz A. (2020). Surgical Repair of Congenital Lateral Luxation of the Patella In An Arabian Foal Using A Polypropylene Mesh. Equine Vet Educ. (Early view).

13. Pagliara E, Cantatore F, Pallante M, Valazza A, Riccio B, Bertuglia A. (2020). Lateral patellar instability in Standardbred horses at the weanling age: Clinical and morphological features in four cases (2017-2019). Equine Vet Educ. (Early View)

14. O'Meara B, Lischer C. (2009). Surgical Management of a Pony with a Traumatic Medial Luxation of the Patella. Equine Vet Educ. 21(9): 458-63.

15. Bosio F, Bufalari A, Peirone B, Petazzoni M, Vezzoni A. Prevalence. (2017). Treatment and Outcome of Patellar Luxation in Dogs in Italy. Vet Comp Orthop Traumatol. 30(05): 364-70.

16. Belge A, Yaygingul R, Sarierler M, Tatlı ZB. (2016). The Effectiveness of Patellar Anti-rotational Suture Techniques on Treatment of Lateral Patellar Luxation in Calves. Kafkas Univ Vet Fak Derg. 22(6):853-857.

17. Slatter DH. (2003). Textbook of Small Animal Surgery. 3. Edition, Elsevier, London.

18. Winstanley E, Gleeson L. (1974). Prosthetic Trochlear Ridge for Treatment of Patellar Luxation in a Calf. J Am Vet Med Assoc.164 (8): 877-808.

19. Fubini S, Ducharme N. (2004). Farm Animal Surgery. 2. edition, Saunders. St Louis.

20. Leitch M, Kotlikoff M. (1980). Surgical Repair of Congenital Lateral Luxation of the Patella in the Foal and Calf. Vet Surg. 9(1): 1-4.

\section{Corresponding Author:}

SItkıcan OKUR

Department of Surgery, Faculty of Veterinary Medicine,

Atatürk University, Erzurum, TURKEY

E-posta: sitkican.okur@atauni.edu.tr 